\title{
PENGEMBANGAN MODEL KURIKULUM PENDIDIKAN EKONOMI UNTUK MENYIAPKAN GURU PROFESIONAL DI SEKOLAH BERTARAF INTERNASIONAL
}

\author{
Dadang Dahlan $^{1}$, Neti Budiwati ${ }^{2}$, Susanti Kurniawati ${ }^{3}$ \\ Program Pendidikan Ekonomi FPEB UPI Bandung \\ E-mail: dadangdhln@gmail.com
}

\begin{abstract}
This study aims to: 1) Generating a description of the graduates competence to prepare economics teacher at the International School (SBI) 2) Generating the substance of the study which relevant with the graduates competence. 3) Producing design curriculum appropriate to the needs of the economy to prepare prospective teachers in SBI. The study was designed for 2 years in the Research and Development, is based on a curriculum development manual competency-based curriculum development of higher education issued by the Directorate General of Higher Education (2008). Results of the study, among others, found that the description of the competence of Education study program consists of a) two core competences b) nine supporting competency and c) four other competencies. Core competencies consist of a) control of the structure, concepts, generalizations, theories, and scientific mindset within the scope of the global economy that consists of 18 sub-competences b) mastery of concepts, theories, and pedagogical principles consisting of 6 sub-competences. Supporting competence consists of 11 subcompetences and other competencies consist of 9 sub-competences. Main competence substance consists of 24 studies, supporting competency consists of 11 studies and other competencies substance consists of 9 substance of the study, so the total credits of students who have taken a number of 152 credits or 61 courses.
\end{abstract}

Keywords: Competence, substance assessment, curriculum design

\begin{abstract}
Abstrak
Penelitian ini bertujuan: 1) Menghasilkan deskripsi kompetensi lulusan untuk menyiapkan guru ekonomi di Sekolah Bertaraf Internasional (SBI) 2) Menghasilkan substansi kajian yang relevan dengan kompetensi lulusan. 3) Menghasilkan desain kurikulum yang sesuai dengan kebutuhan untuk menyiapkan calon guru ekonomi di SBI. Penelitian dirancang untuk 2 tahun dengan menggunakan metode Research and Development, Pengembangan kurikulum ini dilakukan berdasarkan buku panduan pengembangan kurikulum berbasis kompetensi pendidikan tinggi yang diterbitkan oleh Direktorat Jendral Pendidikan Tinggi (2008). Hasil penelitian antara lain ditemukan bahwa deskripsi kompetensi Prodi Pendidikan terdiri dari a) dua kompetensi utama b) sembilan kompetensi pendukung dan c) empat kompetensi lainnya. Kompetensi utama terdiri dari a) penguasaan struktur, konsep, generalisasi, teori, dan pola pikir keilmuan ekonomi dalam lingkup global yang terdiri dari 18 subkompetensi b) penguasaan konsep, teori, dan prinsip pedagogik yang terdiri atas 6 subkompetensi. Kompetensi pendukung terdiri dari 11 subkompetensi dan kompetensi lainnya terdiri dari 9 subkompetensi. Kompetensi Utama terdiri dari 24 substansi kajian, kompetensi pendukung terdiri atas 11 substansi kajian dan kompetensi lainnya terdiri dari 9 substansi kajian, sehingga total SKS yang harus ditempuh mahasiswa sejumlah 152 SKS atau 61 mata kuliah.
\end{abstract}

Kata kunci: Kompetensi, substansi kajian, desain kurikulum

\section{PENDAHULUAN}

Penelitian ini berawal dari suatu pemikiran tentang tantangan di masa depan yang berkaitan dengan kebutuhan guru untuk Sekolah Bertaraf Internasional (SBI), yang memunculkan pertanyaan bagaimana mendesain kurikulum dengan pendekatan berbasis kompetensi dalam rangka menghasilkan calon guru yang sesuai dengan kebutuhan guru di sekolah bertaraf internasional (SBI)?

Penelitian ini bertujuan: 1) Menghasilkan deskripsi kompetensi lulusan untuk menyiapkan guru ekonomi untuk 
Sekolah Bertaraf Internasional (SBI) 2) Menghasilkan substansi kajian yang relevan dengan kompetensi lulusan. 3) Menghasilkan desain kurikulum yang sesuai dengan kebutuhan untuk menyiapkan calon guru ekonomi di SBI.

Penelitian dirancang untuk 2 tahun dengan menggunakan metode Research and Development, untuk pada tahun kedua ini dilakukan pengembangan produk untuk selanjutnya di validasi untuk kepentingan pengembangan model kurikulum. Pengembangan kurikulum ini dilakukan berdasarkan buku panduan pengembangan kurikulum berbasis kompetensi pendidikan tinggi yang diterbitkan oleh Direktorat Jendral Pendidikan Tinggi (2008), dengan melakukan 1) tracer studi, 2) penyusunan profil, 3) perumusan kompetensi, 4) perumusan substansi kajian, 5) perumusan kedalaman dan keluasan bahasan kajian (SKS), dan 6) distribusi mata kuliah persemester.

Kebutuhan terhadap lulusan sekolah yang memiliki kemampuan bertaraf nasional dan internasional semakin meningkat seiring dengan perkembangan globalisasi pendidikan. Upaya pemerintah Indonesia dalam meningkatkan kualitas mutu lulusan untuk menjawab tantangan global tersebut antara lain melalui program Sekolah Bertaraf Internasional (SBI). Indikator rendahnya mutu pendidikan kita dapat dilihat dari prestasi belajar siswa-siswa Indonesia yang jauh tertinggal di banding negara-negara lain. Untuk menghadapi tantangan di masa depan, yang berkaitan dengan kebutuhan guru untuk Sekolah Bertaraf Internasional (SBI) pendidikan guru harus direformasi. Berkaitan dengan hal tersebut di atas, kurikulum merupakan salah satu aspek yang turut mempengaruhi kualitas lulusan LPTK untuk mengajar di SBI.

Secara konseptual akademis, pendidikan guru masa depan harus konsisten pada pendidikan berbasis kompetensi. Hasil pengamatan menunjuk-kan gejala bahwa model kurikulum yang dikembangkan di beberapa program studi di lingkungan perguruan tinggi, belum mengikuti acuan formal dan prosedur baku sebagaimana yang direkomendasikan para pakar kurikulum. Acuan formal yang dimaksud ialah Kepmendiknas No.232/U/ 2000 tentang Pengembangan Kurikulum dan Penilaian Hasil Belajar dan Kepmendiknas No. 045/U/2002 tentang Kurikulum Pendidikan Tinggi. Sedangkan prosedur baku yang direkomendasikan para ahli kurikulum meliputi langkah-langkah pengembangan kurikulum, mulai dari identifikasi kebutuhan, analisis dan pengukuran kebutuhan, penyusunan desain kurikulum, validasi kurikulum (uji coba dan penyempurnaan), implementasi kurikulum, dan evaluasi kurikulum.

Terdapat pergeseran pendekatan dalam pengembangan kurikulum bahwa dasar competent-based approach harus segera menggantikan content-based approach dalam bentuk: (1) penguasaan aspek kognitif dari instrumental dirubah ke bentuk kemampuan; (2) penguasaan aspek afektif dari pragmatis dirubah ke komprehensif; (3) penguasaan aspek psikomotorik dirubah dari bentuk adaptif ke profesional (Pusposutardjo , 2001). Berdasarkan latar belakang tentang orientasi pengembangan kurikulum guru SBI makadirumuskan pertanyaan kuikulum sbagai berikut 1) Bagaimana deskripsi kompetensi (learning outcomes) lulusan prodi Pendidikan Ekonomi sebagai calon guru SBI 2) Bagaimana substansi kajian yang relevan untuk mencapai kompetensi lulusan prodi Pendidikan Ekonomi sebgai calon guru SBI 3) Bagaimana desain kurikulum Pendididikan Ekonomi yang sesuai dengan kebutuhan untuk menghasilkan guru SBI.

Secara umum penelitian ini bertujuan untuk mengembangkan desain kurikulum pendidikan ekonomi untuk calon guru SBI. Tujuan ini dijabarkan menjadi tujuan khusus yaitu 1) menghasilkan standar kompetensi lulusan untuk mempersiapkan guru ekonomi untuk Sekolah Bertaraf Internasional (SBI) 2) Menghasilkan desain kurikulum pendidikan ekonomi untuk calon guru 
SBI. Manfaat praktisnya, penelitian pengembangan kurikulum ini adalah produk yang dihasilkan berupa desain kurikulum inti dapat dimanfaatkan oleh Perguruan Tinggi lain (PTN maupun PTS) di Indonesia yang membuka program pendidikan guru ekonomi untuk kelas internasional dalam rangka menyiapkan calon guru SBI.

Konsep SBI merupakan konsep SNP + $\mathrm{X}$ (OECD) dengan makna SNP singkatan dari Standar Nasional Pendidikan, $\mathrm{X}$ adalah penguatan, pengayaan, pengembangan, perluasan, pendalaman, melalui adaptasi atau adopsi terhadap standar pendidikan baik dari dalam negeri maupun luar negeri yang telah memiliki reputasi mutu yang diakui secara internasional misalnya saja Cambridge, IB, dan TOEFL/TOEIC. Dalam hal ini SBI memiliki karaktristik memiliki 1)Visi dan Misi 2) High Standards and Expectations for All Students. 3) Effective School Leadership 4) High Levels of Collaboration \& Communication 5) Curriculum, Instruction and Assessment Aligned with Standards. 6) Tersedia Media Resource Centre. Perpustakaan cukup luas, memiliki tempat belajar bagi para siswa, koleksi sangat lengkap; tersedia program remedial; tersedia program pengayaan. 7) Frequent Monitoring of Learning and Teaching. 8) Focused Professional Development. Secara periodik mengirim guru, tenaga kependidikan untuk mengikuti pelatihan. Pelatihan yang diikuti didasarkan atas kebutuhan sekolah; 9) Supportive Learning Environment. 10) High Level of Family and Community Involvement.

Kurikulum yang berlaku sekarang dinilai belum mampu menghasilkan kompetensi yang memenuhi kebutuhan SBI. Dengan demikian, perlu dilakukan pengembangan model kurikulum. Di dalam khasanah ilmu kurikulum, dapat dibedakan empat macam model kurikulum, yakni Kurikulum Berbasis Kompetensi (KBK), Kurikulum Berbasis Ilmu (KBI), Kurikulum Berbasis Siwa (KBS), dan Kurikulum Berbasis Masalah Sosial (KBMS) (Sukmadinata, 2004). Kurikulum yang paling sesuai dengan kebutuhan PT adalah kurikulum yang berbasis kompetensi.

Selain itu, pengembangan model kurikulum ini mengacu pada KKNI yang diajukan oleh Ditjen dikti yang tercantum dalam buku pedoman KKNI. Menurut Buku Pedoman KKNI yang diterbitkan Ditjen Dikti (2010), Kerangka Kualifikasi Nasional Indonesia (KKNI) adalah kerangka penjenjangan kualifikasi dan kompetensi tenaga kerja Indonesia yang menyandingkan, menyetarakan, dan mengintegrasikan sektor pendidikan dengan sektor pelatihan dan pengalaman kerja dalam suatu skema pengakuan kemampuan kerja yang disesuaikan dengan struktur di berbagai sektor pekerjaan. Dalam pedoman tersebut, dijelaskan pula bahwa KKNI disusun berdasarkan kebutuhan dan tujuan khusus untuk menyelaraskan sistem pendidikan dan pelatihan dengan sistem karir di dunia kerja. KKNI menyediakan sembilan jenjang kualifikasi, dimulai dari Kualifikasi jenjang 1 sebagai kualifikasi terendah dan kualifikasi jenjang 9 sebagai kualifikasi tertinggi. Setiap jenjang kualifikasi dalam KKNI disusun oleh empat parameter utama yaitu (a) keterampilan kerja, (b) cakupan keilmuan/pengetahuan, (c) metoda dan tingkat kemampuan dalam mengaplikasikan keilmuan/pengetahuan tersebut serta (d) kemampuan manajerial.

Jenjang kompetensi yang mengindikasikan kompetensi capaian tingkat sarjana adalah jenjang 6, kompetensi yang harus di capai pada jenjang ini adalah 1) mampu memanfaatkan IPTEKS dalam bidang keahliannya, dan mampu beradaptasi terhadap situasi yang dihadapi dalam penyelesaian masalah. 2) Menguasai konsep teoritis bidang pengetahuan tertentu secara umum dan konsep teoritis bagian khusus dalam bidang pengetahuan tersebut secara mendalam, serta mampu memformulasikan penyelesaian masalah prosedural.3) mampu mengambil keputusan strategis berdasarkan analisis informasi dan data, dan memberikan petunjuk dalam memilih berbagai alternatif solusi.4) Bertanggung jawab pada pekerjaan sendiri dan 
dapat diberi tanggung jawab atas pencapaian hasil kerja organisasi.

Sebagaimana telah disinggung dalam bagian pendahuluan, desain kurikulum program studi merupakan perpaduan antara komponen kurikulum inti dan komponen kurikulum institusional. Lebih lanjut dijelaskan dalam Kepmendiknas 45/U/2002 bahwa kurikulum inti suatu program studi memiliki karakteristik: (1) sebagai dasar untuk mencapai kompetensi lulusan ; (2) acuan baku minimal mutu penyelenggaraan program studi; (3) berlaku secara nasional dan internasional; (4) lentur dan akomodatif terhadap perubahan yang sangat cepat di masa mendatang; (5) merupakan kesepakatan bersama antara kalangan perguruan tinggi, masyarakat profesi, dan pengguna lulusan. Di samping komponen kurikulum inti, kurikulum utuh program studi memuat pula komponen institusional yang dikembangkan oleh masing-masing lembaga. Komponen institusional dikembangkan untuk mencapai kompetensi pendukung dan kompetensi lain yang bersifat khusus dan relevan dengan kompetensi utama.

Materi yang dikembangkan dalam komponen kurikulum inti maupun komponen institusional baru berupa substansi kajian (konsep/topik), dan belum berbentuk mata kuliah. Setelah dikembangkan substansi kajian, kemudian dilakukan pengemasan substansi kajian ke dalam mata kuliah dengan memper-timbangkan faktorfaktor: (1) homogenitas, di mana berbagai substansi tersebut dinilai sejenis dan/atau saling berkaitan; (2) kelaikan/keterlaksanaan dimana cakupan isi suatu mata kuliah tidak terlalu banyak sehingga melampaui bobot maksimum SKS yang berlaku (Ibrahim, 2005:20). Pengelompok-kan mata kuliah di perguruan tinggi menurut Kepmendiknas No.232/U /2000, terdiri dari kelompok mata kuliah: (1) penghayatan nilai dan kepribadian (MPK); (2) keilmuan keterampilan (MKK); (3) keakhlian berkarya (MPB); (4) perilaku berkarya (MPB); (5) berkehidupan ber-masyarakat (MBB).
Kelompok mata kuliah ini diturunkan dari pilar-pilar pendidikan : (1) learning to be morally; (2) learning to know ; (3) learning to do; (4) learning to know; (5) learning to live together.

\section{METODOLOGI PENELITIAN}

Rancangan yang digunakan dalam penelitian ini adalah rancangan Research and Development (R\&D) atau model penelitian, penilaian dan pengembangan (Research, Development and Evaluation atau $\mathrm{R}, \mathrm{D} \& \mathrm{E}$ ). yang ditempuh melalui studi literatur, dokumentasi dan survey (tahap pertama), dan diakhiri dengan studi eksperimen (tahap kedua) untuk kepentingan validasi model.

Penelitian ini akan dilakukan di Kota dan Kabupaten Bandung, dengan subjek penelitian terdiri atas mahasiswa, dosen, alumni, guru, dan stakeholders lain sebagai dengan pemakai lulusan. Alumni dan guruguru yang dilibatkan sebagai responden adalah mereka yang mengajar di RSBI di kota dan kabupaten Bandung, yang meliputi SMA Negeri 3 Bandung, SMA Negeri 5 Bandung, SMAS Terpadu Krida Nusantara, SMA Negeri 1 Bale Endah, SMA Negeri 1 Cisarua. Teknik pengumpulan data yang digunakan untuk mengumpulkan data dalam penelitian ini adalah angket (kuesioner) dan wawancara.

\section{HASIL DAN PEMBAHASAN}

Hasil penelitian antara lain ditemukan bahwa deskripsi kurikulum Prodi Pendidikan terdiri dari a) dua kompetensi utama b) sembilan kompetensi pendukung dan c) empat kompetensi lainnya. Kompetensi utama terdiri dari a) penguasaan struktur, konsep, generalisasi, teori, dan pola pikir keilmuan ekonomi dalam lingkup global yang terdiri dari 18 subkompetensi yang merujuk pada sub-kompetensi dalam kajian ekonomi makro, mikro, kebijakan ekonomi, ekonomi islam, dan UMKM b) penguasaan konsep, teori, dan prinsip pedagogic yang terdiri atas 6 subkompetensi yang secara garis besar meliputi penguasaan dalam 
perencanan pembelajaran, pelaksanaan dan penilaian proses pembelajaran. Kompetensi pendukung terdiri dari 11 subkompetensi yang meliputi penguasaan bahasa asing (bahasa Inggris), penguasaan alat ukur, penguasaan ICT dan penelitian. Sedangkan kompetensi lainnya terdiri dari 9 subkompetensi yang meliputi penguasaan manajemen, akuntansi dan bisnis global.

Kompetensi Utama terdiri dari 24 substansi kajian, kompetensi pendukung terdiri atas 11 substansi kajian dan kompetensi lainnya terdiri dari 9 substansi kajian. Desain kurikulum yang tersusun terdiri atas 6 kelompok mata kuliah terdiri atas 1) 16 SKS Kelompok Mata Kuliah Umum (General Courses) 2) 12 SKS Kelompok mata kuliah Pedagogik Umum (Professional Foundation Courses) 3) 8 SKS Kelompok mata kuliah Pedagogik Khusus (Spesific Pedagogy)/Professional competencies courses 4) 12 SKS Kelompok mata kuliah Keahlian (MKK) Fakultas/ General Economic and Business Courses 5)100 SKS Kelompok mata kuliah Keahlian (MKK) Prodi/Economic Education Competencies Courses 6)12 SKS Kelompok Mata Kuliah Keilmuan dan Keahlian Pilihan/Optional Courses untuk dipilih 4 SKS dari mata kuliah yang ditawarkan. Sehingga total SKS yang harus ditempuh adalah 152 SKS atau 61 mata kuliah.

Penelitian ini hanya memfokuskan pada perumusan kompetensi kelompok mata kuliah keahlian fakultas (General Economic and Business Courses), kelompok mata kuliah Keahlian (MKK) Prodi/Economic Education Competencies Courses dan Kelompok Mata Kuliah Keilmuan dan Keahlian Pilihan/Optional Courses. Untuk rumusan kompetensi dan substansi kajian kelompok mata kuliah Mata Kuliah Umum (General Courses, kelompok mata kuliah Pedagogik Umum (Professional Foundation Courses, kelompok mata kuliah Pedagogik Khusus (Spesific Pedagogy)/Professional competencies courses mengikuti aturan yang telah ditetapkan universitas (UPI).

\section{PENUTUP Simpulan}

Deskripsi kompetensi yang telah dirumuskan untuk calon guru ekonomi di SBI terdiri dari kompetensi utama, kompetensi pendukung, dan kompetensi lainnya. Kompetensi utama terdiri dari 24 sub kompetensi, kompetensi pendukung 11 sub kompetensi, dan kompetensi lainnya terdiri dari 9 sub kompetensi. Substansi kajian yang telah dirumuskan meliputi substansi kajian kompetensi utama sejumlah 24, substansi kajian kompetensi pendukung sejumlah 11,dan substansi kajian kompetensi lainnnya sejumlah 9. Desain kurikulum yang telah dikembangkan terdiri dari 6 kelompok mata kuliah dengan beban 152 SKS ; 1) 16 SKS Kelompok Mata Kuliah Umum (General Courses)2) 12 SKS Kelompok mata kuliah Pedagogik Umum (Professional Foundation Courses)3) 8. SKS Kelompok mata kuliah Pedagogik Khusus (Spesific Pedagogy)/Professional competencies courses 4) 12 SKS Kelompok mata kuliah Keahlian (MKK) Fakultas/General Economic and Business Courses 5)100 SKS Kelompok mata kuliah Keahlian (MKK) Prodi/Economic Education Competencies Courses 6)12 SKS Kelompok Mata Kuliah Keilmuan dan Keahlian Pilihan/Optional Courses.

\section{Saran}

Bertitik tolak dari hasil penelitian ini disarankan bahwa desain kurikulum yang telah dikembangkan ditindaklanjuti dengan 1) penyusunan silabus dan Satuan Acara Perkuliahan (SAP) berbasis kompetensi yang penyusunannya melibatkan pihak “" stakeholders " (dosen dan guru ekonomi di RSBI) 2) penyusunan/ pengembangan bahan ajar bilingual, terutama untuk kelompok mata kuliah keakhlian (MKK) yang didahului dengan pelatihan pengembangan bahan ajar bilingual. 3) Silabus, SAP dan bahan ajar bilingual yang telah disusun, agar dicobakan di kelas, agar dapat diketahui efektivitas proses dan hasil perkuliahan 4) Implementasi kurikulum/ pembelajaran 
menggunakan berbagai pendekatan pembelajaran sesuai dengan tuntutan kurikulum 5) perancang kurikulum disarankan mengacu kepada standar kompetensi lulusan (SKL) yang memungkinkan lulusan bisa berkerja secara efektif pada SBI dan mampu bersaing di tingkat global.

\section{DAFTAR PUSTAKA}

Ibrahim, R. (2005). " Pengembangan Kurikulum Program Studi Di Perguruan Tinggi Dengan Penekanan Khusus Pada LPTK" Jurnal EduTech, Vol. 2 No. 2 ; 13-22

Pramuniati, I. (2008). Mengejar Ketertinggalan Melalui Implementasi Pendidikan Bertaraf Internasional, Makalah Konvensi Nasional Pendidikan VI, Denpasar: UNDIKSHA

Pusat Kurikulum BALITBANG DEPDIKNAS. (2007). Model Kurikulum Sekolah Bertaraf Internasional. Jakarta: DEKDIKNAS

Pusposutardjo, S. (2001). "Penjelasan Kurikulum Nasional Menurut Kep.
Mendiknas No.232/U/2000". PGSM Dirjen Dikti.

Sukmadinata., Syaodih., \& Nana. (2004). Kurikulum dan Pembelajaran Kompetensi. Bandung : Kesuma Karya

Tim Pengembang Kurikulum. (2012). Rambu-Rambu Pengembangan Kurikulum Universitas Pendidikan Indonesia (UPI).Bandung: UPI

Universitas Pendidikan Indonesia. (2011). Ketentuan Pokok Pengembangan Kurikulum Universitas Pendidikan Indonesia: Bandung: UPI.

Wardani, I. G. A. K. (2003). Kurikulum Berbasis Kompetensi, Apa, Mengapa, Dan Bagaimana Implementasinya. Jurnal Pendidikan dan Kebudayaan 4 (1): $37-47$

Wiyastono, H. (1999). Pengembangan Kurikulum Pendidikan Tinggi : Suatu Kajian Yuridis, Teoritis, dan Empiris. Jurnal Pendidikan dan Kebudayaan No.018, hal 67-81.

Yulaelawati, E. (2003). Kurikulum Berbasis Kompetensi. Jakarta : Depdiknas 